\title{
Task 4 Report
}

\section{Production of Hydrogen by Thermocatalytic Cracking of Natural Gas}

DOE/AL/85802-T2-Pt.4

Annual Report

FSEC-CR-857-95 DOE Contract \#DE-FG04-94AL85802 October 1995

Submitted to:

Neil Rossmeissl Advanced Utility Concepts Division Department of Energy Washington, DC 20585

DGTRREUTION OF THIS DOCUNENT IS UNTHATED h

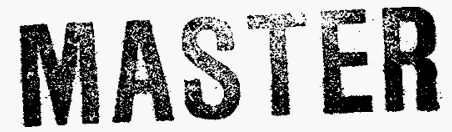

Submitted by: Nazim Z. Muradov Florida Solar Energy Center 1679 Clearlake Road Cocoa, Florida 32922-5703 


\section{DISCLAIMER}

This report was prepared as an account of work sponsored by an agency of the United States Government. Neither the United States Government nor any agency thereof, nor any of their employees, make any warranty, express or implied, or assumes any legal liability or responsibility for the accuracy, completeness, or usefulness of any information, apparatus, product, or process disclosed, or represents that its use would not infringe privately owned rights. Reference herein to any specific commercial product, process, or service by trade name, trademark, manufacturer, or otherwise does not necessarily constitute or imply its endorsement, recommendation, or favoring by the United States Government or any agency thereof. The views and opinions of authors expressed herein do not necessar. ily state or reflect those of the United States Government or any agency thereof. 


\section{DISCLAIMER}

Portions of this document may be illegible electronic image products. Images are produced from the best available original document. 


\title{
PREFACE
}

This report describes the Sustainable Hydrogen Production research conducted at the Florida Solar Energy Center (FSEC) for the past year. The report presents the work done on the following four tasks:

Task 1. Production of Hydrogen by Photovoltaic-Powered Electrolysis - This task represents the final effort of a cooperative project between the U.S. Department of Energy, NASA/Kennedy Space Center, FSEC and the Florida Energy Office. The activities covered five years of effort at a total funding of $\$ 216,809$. These results represent a successful coordination of two state agencies and two federal agencies.

Task 2. Solar Photocatalytic Hydrogen Production from Water Using a Dual-Bed Photosystem - This task established the basis of the dual-bed concept by selectively evolving hydrogen or oxygen. A number of redox mediators were found to facilitate hydrogen production.

Task 3. Development of Solid Electrolytes for Water Electrolysis at Intermediate Temperatures - Several ionomers were synthesized and fabricated into proton exchange membranes. Laboratory testing in an electrolysis cell gave comparable performance to the commercial product.

Task 4. Production of Hydrogen by Thermocatalytic Cracking of Natural Gas - The experimental unit was constructed and a number of catalysts for methane cracking reactions were tested. Laboratory experiments established catalysi activity and identified stability problems.

This report was prepared by the Florida Solar Energy Center/University of Central Florida as an account of work sponsored by the U.S. Department of Energy (Contract \#DE-FG0494AL85802)). The work reported in this document does not imply endorsement by U.S. Department of Energy.

\author{
David L. Block \\ Clovis Linkous \\ Nazim Muradov
}

\section{DISCLAIMER}

\begin{abstract}
This report was prepared as an account of work sponsored by an agency of the United States Government. Neither the United States Government nor any agency thereof, nor any of their employees, makes any warranty, express or implied, or assumes any legal liability or responsibility for the accuracy, completeness, or usefulness of any information, apparatus, product, or process disclosed, or represents that its use would not infringe privately owned rights. Reference herein to any specific commercial product, process, or service by trade name, trademark, manufacturer, or otherwise does not necessarily constitute or imply its endorsement, recommendation, or favoring by the United States Government or any agency thereof. The views and opinions of authors expressed herein do not necessarily state or reflect those of the United States Government or any agency thereof.
\end{abstract}




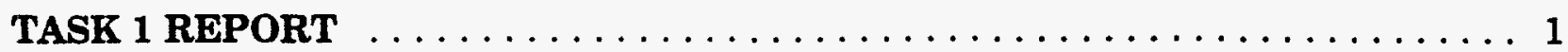

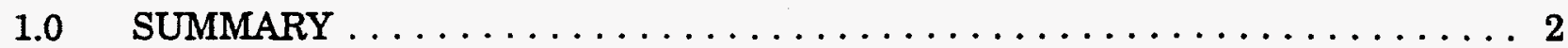

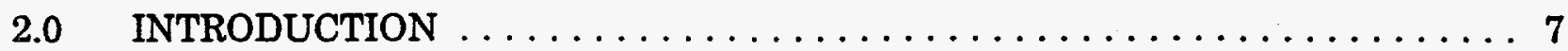

$3.0 \quad$ RESULTS $\ldots \ldots \ldots \ldots \ldots \ldots \ldots \ldots \ldots \ldots \ldots \ldots \ldots \ldots$

3.1 Line Focus Concentrating PV Electrolvsis Hydrogen Production . . . . . 8 8

3.1.1 Concept Description $\ldots \ldots \ldots \ldots \ldots \ldots \ldots \ldots \ldots \ldots \ldots \ldots$

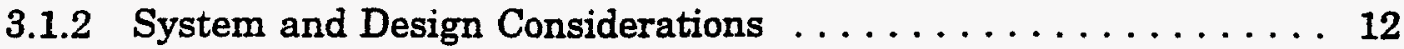

3.1.3 Hydrogen Production Results . . . . . . . . . . . . 14

3.2 Cost of Hydrogen Produced from Photovoltaic Electrolysis $\ldots \ldots \ldots \ldots 17$

3.2.1 Photovoltaic Efficiencies, Power Output and Costs . . . . . . . 17

3.2.2 Electrolyzer Performance and Gaseous Hydrogen Production .... 19

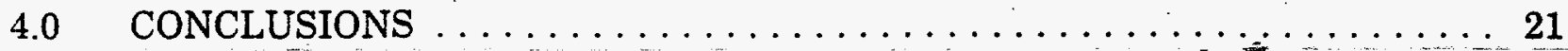

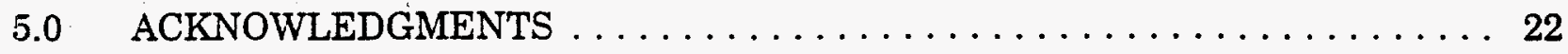

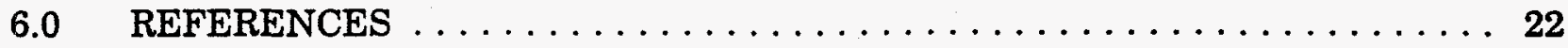

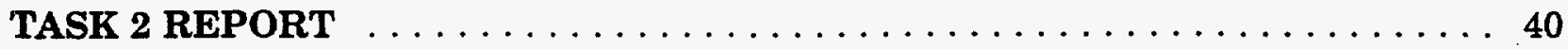

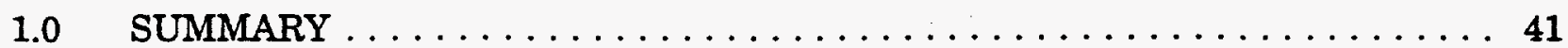

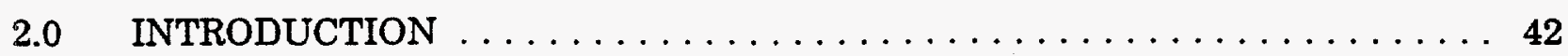

$3.0 \quad$ DESCRIPTION OF CONCEPT $\ldots \ldots \ldots \ldots \ldots \ldots \ldots \ldots \ldots \ldots \ldots \ldots$

$4.0 \quad$ RESULTS $\ldots \ldots \ldots \ldots \ldots \ldots \ldots \ldots \ldots \ldots \ldots \ldots \ldots \ldots \ldots \ldots$

4.1 Theorv: Band Structure of Catalyst/Photoparticle Configurations ..... 48

4.2 Redox Mediator Photochemistry $\ldots \ldots \ldots \ldots \ldots \ldots \ldots \ldots, \ldots \ldots$

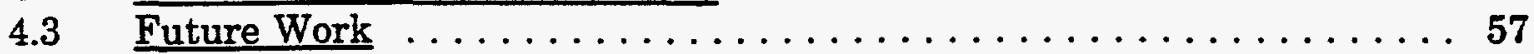

$5.0 \quad$ ACKNOWLEDGMENT $\ldots \ldots \ldots \ldots \ldots \ldots \ldots \ldots \ldots \ldots \ldots \ldots$

TASK 3 REPORT $\ldots \ldots \ldots \ldots \ldots \ldots \ldots \ldots \ldots \ldots \ldots \ldots \ldots \ldots$

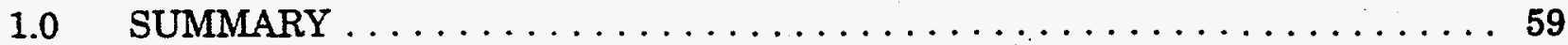

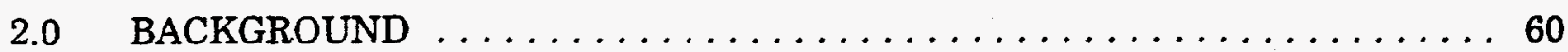

2.1 Advantages in Performing Water Electrolysis at Elevated Temperature . 60

2.2 Current Proton Exchange Membrane Technology ............6 61

2.3 Development of Intermediate Temperature Solid Electrolvtes $\ldots \ldots \ldots 62$

$2.4 \quad$ Previous Work on Engineering Polymers $\ldots \ldots \ldots \ldots \ldots \ldots 63$ 


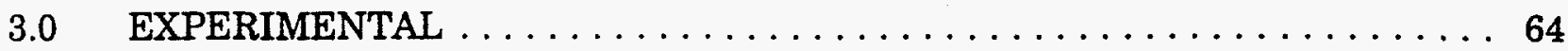

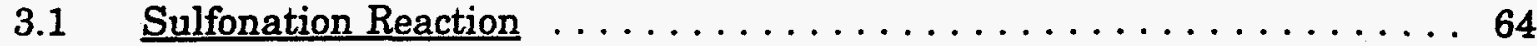

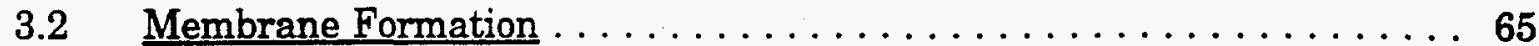

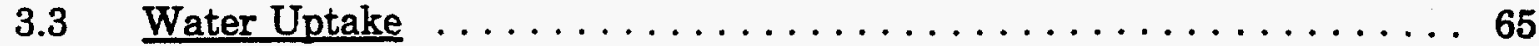

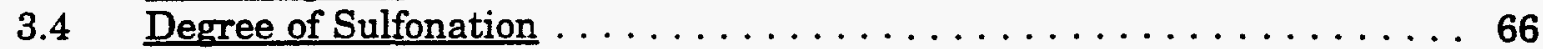

3.5 Thermo-Conductimetric Analysis $\ldots \ldots \ldots \ldots \ldots \ldots \ldots \ldots \ldots$

3.6 Electrolysis Performance $\ldots \ldots \ldots \ldots \ldots \ldots$

$4.0 \quad$ RESULTS AND DISCUSSION $\ldots \ldots \ldots \ldots \ldots \ldots \ldots \ldots$

$4.1 \quad$ Ionomer Synthesis and Membrane Fabrication . . . . . . . . . . . 68

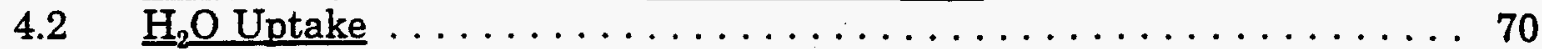

4.3 Thermoconductimetric Results $\ldots \ldots \ldots \ldots \ldots \ldots \ldots \ldots \ldots \ldots \ldots \ldots$

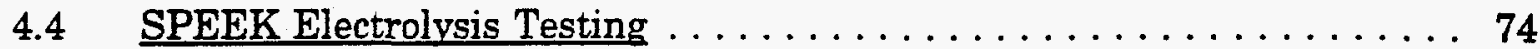

$5.0 \quad$ CONCLUSION $\ldots \ldots \ldots \ldots \ldots \ldots \ldots \ldots \ldots \ldots \ldots \ldots \ldots$

6.0 ACKNOWLEDGMENTS $\ldots \ldots \ldots \ldots \ldots \ldots \ldots \ldots \ldots \ldots$

$7.0 \quad$ REFERENCES $\ldots \ldots \ldots \ldots \ldots \ldots \ldots \ldots \ldots \ldots \ldots \ldots \ldots \ldots \ldots$

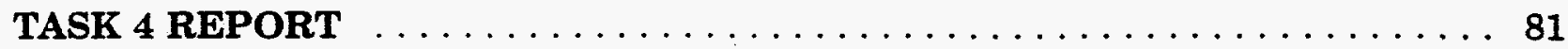

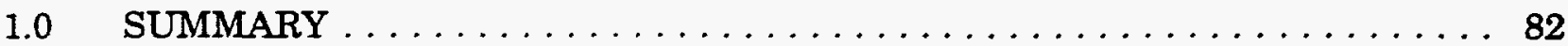

$2.0 \quad$ INTRODUCTION $\ldots \ldots \ldots \ldots \ldots \ldots \ldots \ldots \ldots \ldots \ldots \ldots \ldots \ldots$

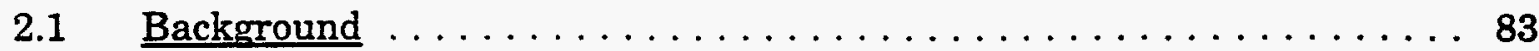

2.2 Thermal Cracking of Methane $\ldots \ldots \ldots \ldots \ldots \ldots \ldots$

2.3 Thermocatalytic Decomposition of Methane $\ldots \ldots \ldots \ldots$

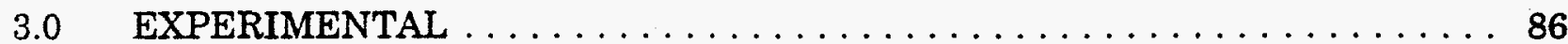

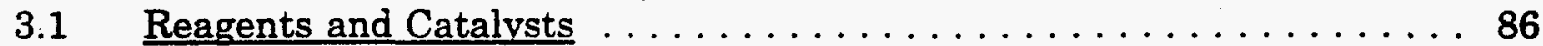

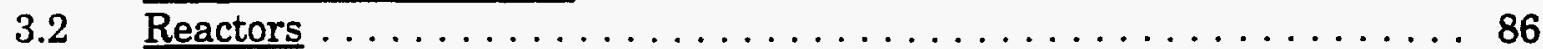

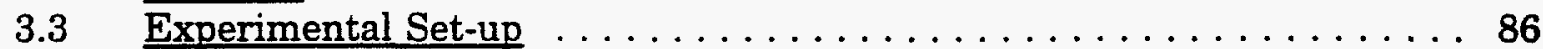

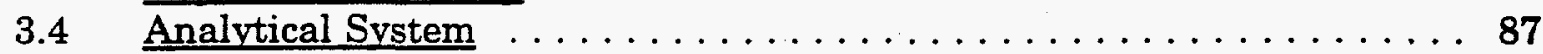

$4.0 \quad$ RESULTS AND DISCUSSION $\ldots \ldots \ldots \ldots \ldots \ldots \ldots \ldots \ldots \ldots \ldots$

4.1 Temperature Dependence of Hydrogen Yield $\ldots \ldots \ldots \ldots \ldots \ldots$

4.2 Space Velocity Dependence of Hydrogen Yield $\ldots \ldots \ldots \ldots \ldots \ldots$

$4.3 \quad$ Pulse Reactor Experiments $\ldots \ldots \ldots \ldots \ldots \ldots \ldots$

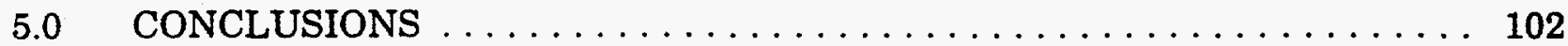

$6.0 \quad$ REFERENCES $\ldots \ldots \ldots \ldots \ldots \ldots \ldots \ldots \ldots \ldots \ldots \ldots \ldots \ldots$ 


\subsection{SUMMARY}

In the next few decades hydrogen production will continue to rely on fossil fuels (primarily, natural gas). The conventional methods of hydrogen production from natural gas, for example, steam reforming (SR), are complex multi-step processes. These processes also result in the emission of large quantities of $\mathrm{CO}_{2}$ into the atmosphere. One alternative is the single-step thermocatalytic cracking (TCC) (or decomposition) of natural gas into hydrogen and carbon. The comparative assessment of SR and TCC processes was conducted.

The series of experiments on the thermocatalytic cracking of methane over various catalysts and supports in a wide range of temperatures $\left(500-900^{\circ} \mathrm{C}\right)$ and flow rates was conducted at the Florida Solar Energy Center. Two types of fix bed catalytic reactors were designed, built and tested: continuous flow and pulse reactors. The temperature dependence of the hydrogen production yield using metal and metal oxide type catalysts was studied. Ni-Mo/Alumina and $\mathrm{Fe}$-catalysts demonstrated relatively high efficiency in the methane cracking reaction at the range of temperatures $600-800^{\circ} \mathrm{C}$. Fe-catalyst demonstrated fairly good stability, whereas alumina-supported Pt-catalyst rapidly lost its catalytic activity. Methane decomposition reaction over $\mathrm{Ni}-\mathrm{Mo} /$ alumina was studied over wide range of space velocities (3.8-67.8 $\mathrm{min}^{-1}$ ) in a continuous flow fixed bed catalytic reactor. The experimental results indicate that the hydrogen yield decreases noticeably with an increase in the space velocity of methane. The pulse type catalytic reactor was used to test the activity of the catalysts. It was found that induction period on the kinetic curve of hydrogen production corresponded to the reduction of metal oxide to metallic form of the catalyst. SEM method was used to study the structure of the carbon deposited on the catalyst surface. 


\subsection{INTRODECTION}

\subsection{Background}

Energy systems based on hydrogen as an energy carrier coupled with renewable energy resources are considered as ultimate long term option. Natural gas appears to be a viable near term option. According to Marchetti (1979) and Nakicenovic (1990), natural gas will become, globally, the major source of energy during the next century. It is widely accepted that in the short- to medium-term hydrogen production will continue to rely on natural gas. On the other hand, the use of natural gas as a chemical feedstock and a fuel for the conventional processes of hydrogen production, for example, steam reforming (SR) or partial oxidation (PO), results in the emission of large quantities of $\mathrm{CO}_{2}$ that produce adverse ecological effects. SR of natural gas is a complex process consisting of four processing steps:

1) feedstock purification

2) steam reforming of methane to hydrogen and carbon monoxide:

$$
\mathrm{CH}_{4}+\mathrm{H}_{2} \mathrm{O}-\mathrm{CO}+3 \mathrm{H}_{2}+206 \mathrm{~kJ}
$$

3) water-gas shift reaction:

$$
\mathrm{CO}+\mathrm{H}_{2} \mathrm{O}-\mathrm{CO}_{2}+\mathrm{H}_{2}-41 \mathrm{~kJ}
$$

4) gas purification $\left(\mathrm{CO}_{2}\right.$ removal $)$

The reforming reaction is a strongly endothermic, high temperature $\left(800-900^{\circ} \mathrm{C}\right)$ process. To ensure a maximum conversion of $\mathrm{CH}_{4}$ into the products, the process generally employs an excess of steam (steam/carbon ratio 3-5). The process thermal efficiency of the steam reformer is seldom greater than 50\% (Cromarty 1992). Because of the energy intensive stages of SR process the usage of natural gas as a fuel is almost equal to its usage as a chemical feedstock. As a result the production of every cubic meter of hydrogen is accompanied by the emission of 0.5 cubic meter of $\mathrm{CO}_{2} . \mathrm{CO}_{2}$ can be removed from flue gases by several methods (e.g. adsorption by molecular sieves, cryogenic separation, membrane separation, etc.) which are energy and 
investment intensive processes. However the real problem is what to do with accumulating volumes of $\mathrm{CO}_{2}$ that are not released into the atmosphere. Simple calculations indicate that the amounts of $\mathrm{CO}_{2}$ generated by reforming/scrubbing process would be truly enormous: the disposal of 10 millions tons of $\mathrm{CO}_{2}$ would be the price to pay for each million ton of hydrogen produced. Although several proposals have been reported in literature (for example, Cheng and Steinberg 1986) on $\mathrm{CO}_{2}$ disposal in natural underground reservoirs, depleted natural gas fields, the deep ocean, etc., concern was expressed by some experts on the possible ecological effects of high concentrations of $\mathrm{CO}_{2}$ in the ocean or other disposal sites on the local biosphere (Nakicenovic 1993).

\subsection{Thermal Cracking of Methane}

One alternative to SR is a single-step thermal cracking (TC) of natural gas into hydrogen and carbon:

$$
\mathrm{CH}_{4} \rightarrow \mathrm{C}+2 \mathrm{H}_{2}+75.6 \mathrm{~kJ}
$$

The energy requirement per mole of hydrogen produced for $\mathrm{TC}$ is somewhat less than that for SR reaction: 37.8 and $41.2 \mathrm{~kJ} / \mathrm{mole}_{2}$ respectively. The process is slightly endothermic, so only an insignificant amount of hydrogen produced could be used as a source of the thermal energy for the process. The $\mathrm{H}_{2} / \mathrm{CH}_{4}$ ratio for both $\mathrm{TC}$ and $\mathrm{SR}$ processes is approximately 2 (considering fuel usage of methane). In addition to hydrogen as a major product, the process produces a very important by-product: clean carbon.

A comparative assessment of hydrogen production processes by TC and SR of natural gas yields the following conclusions:

1) The energy and feedstock consumption per unit of hydrogen produced for the processes are comparable.

2) TC of natural gas is a technologically simple one-step process without energy and material intensive gas separation stages, while SR is a multi-step process. 
3) The maximum temperature of the $\mathrm{SR}$ process is still high $\left(815^{\circ} \mathrm{C}\right)$ despite many decades of intensive operation and improvement. This leaves a very low probability for further reductions in the reaction temperature. In contrast, the TC process has a great potential for decreasing the maximum temperature of the process (by several hundred degrees centigrade) by using effective catalysts.

4) There is a very valuable by-product of TC process: pure carbon, while SR produces no useful by-products.

5) TC produces practically no $\mathrm{CO}_{2}$ emissions.

It was shown (Steinberg and Cheng 1988) that the cost of hydrogen produced by TC of natural gas is somewhat lower than that for the conventional processes and is equal to $\$ 1.64$ per $10^{3}$ SCF after by-product carbon credit is taken.

\subsection{Thermocatalutic Decomposition of Methane}

The thermodynamic data show that the methane decomposition can be realized at relatively moderate temperatures. Thus, the use of catalysts is needed for the realization of thermal decomposition of methane at comparatively low temperatures. Attempts have been made to use catalysts for the cracking of methane and light hydrocarbons. For example, authors used alumina, silica-alumina, silica-magnesia, etc. at $800-1000^{\circ} \mathrm{C}$ (Pobleny and Scott 1966) and Co, $\mathrm{Cr}, \mathrm{Ni}$, Pt-based catalysts at $895-1100^{\circ} \mathrm{C}$ (Callahan 1974). The carbon produced was then burned off the surface of the catalyst.

In this regard, these processes exhibit no significant advantages over conventional processes (for example, $\mathrm{SR}$ ) because of high operational temperatures and large $\mathrm{CO}_{2}$ emissions.

Our approach is based on the selection of the active catalysts for the methane decomposition operating at moderate temperatures $\left(650-850^{\circ} \mathrm{C}\right)$ and carbon recovery. It is more attractive from technical and ecological points of view to store carbon rather than $\mathrm{CO}_{2}$. Since TCC of natural gas does not produce $\mathrm{CO}_{2}$ emissions it can be considered as a transition process linking the fossil fuel and the renewable energy resource-based economies. In the short-term, this process can be used for on-site production of hydrogen-methane mixtures in gas-filling stations and for $\mathrm{CO}_{2}$-free production of hydrogen for fuel cell driven prime movers. 


\subsection{EXPERIMENTAL}

\subsection{Reagents and Catalysts}

The gases: methane (99.0\%, BITEC) and nitrogen (99.999\%, BITEC) were used without further purification. Pt(1\%)/alumina catalyst was prepared by soaking-drying technique using $\gamma$ alumina and $1 \%$ w solution of $\mathrm{H}_{2} \mathrm{PtCl}_{6}$, with subsequent reduction in a stream of hydrogen. Fecatalyst was prepared from $\mathrm{Fe}_{2} \mathrm{O}_{3}$ (Fisher). $\mathrm{NiO}-\mathrm{MoO}_{3} /$ alumina catalyst (surface area $180 \mathrm{~m}^{2} / \mathrm{g}$, pore volume $0.5 \mathrm{~cm}^{3} / \mathrm{g}$ ) was provided by Haldor Topsoe, Inc.

\subsection{Reactors}

Some consideration was given to the reactor material. We studied the catalytic activity of various materials which could potentially be used for the reactor construction for methane decomposition process. A quartz was found to be the most inert material in methane cracking reaction followed by alumina. Metals (e.g.stainless steel demonstrated noticeable catalytic activity in methane decomposition process and can not be used a reactor material in the catalyst activity measurements.

Two types of catalytic reactors were used in this work: continuous flow (material-quartz, reaction zone volume $58.4 \mathrm{~mL}$, catalyst amount 3-6 g) and pulse (material-quartz, reaction zone volume $3.2 \mathrm{~mL}$, catalyst amount $0.5 \mathrm{~g}$ ). Both continuous flow and pulse catalytic reactors were made out of quartz tubes with O.D. $15 \mathrm{~mm}$ and $7 \mathrm{~mm}$, respectively.

\subsection{Experimental Set-up}

The schematic diagram of the catalytic system with continuous flow reactor is depicted in Figure 1. The experimental set-up consists of 3 subsystems: fixed bed catalytic reactor, gas introduction and sampling subsystem and analytical subsystem. The reactor is placed in a temperature-controlled (Love Controls Corp.) oven. Ovens were manufactured by Thermcraft Inc. $\mathrm{CH}_{4}$ and $\mathrm{N}_{2}$ flow rates were measured by flowmeters MKS Instruments, Inc. and Teledyne, Hastings-Raydist, respectively. Before introducing methane into the continuous flow reactor at the operational temperatures and flow rates, slow flow of nitrogen $(25 \mathrm{~mL} / \mathrm{min})$ was passed through the reactor to remove air. At the end of the experiment, the flow of nitrogen was again introduced into the reactor to remove metane and hydrogen from hot reactor. 
Figure 2 depict the schematic diagram of the catalytic system with pulse reactor which consists of a microreactor (volume $3.2 \mathrm{~mL}$ ) with a catalyst, 6-port sampling valve with $1 \mathrm{~mL}$ sampling loop and gas chromatograph. In a "stand-by" position of 6-port valve the carrier gas (nitrogen) entered in tandem the 6-port valve, the microreactor and GC-column. Methane entered $1 \mathrm{~mL}$ sampling loop and vented off. In the "injection" position of the 6-port valve, the pulses ( $1 \mathrm{~mL}$ each) of methane were injected into the microreactor and the methane cracking products entered GC.

\subsection{Analytical System}

The products of methane decomposition and partial oxidation were measured gaschromatographically. Gas chromatograph SRI 8610 (nitrogen-carrier gas, thermal conductivity detector, silicagele column) was used for the analysis of hydrogen. Varian 3000 (helium-carrier gas, flame-ionization detector, Hysep $\mathrm{D}_{\mathrm{B}}$ column) was used for $\mathrm{CO},{ }_{2} \mathrm{CO}$ and traces of hydrocarbons analysis. SEM (Amray 1810) was used to study the carbon deposited on the catalyst surface 


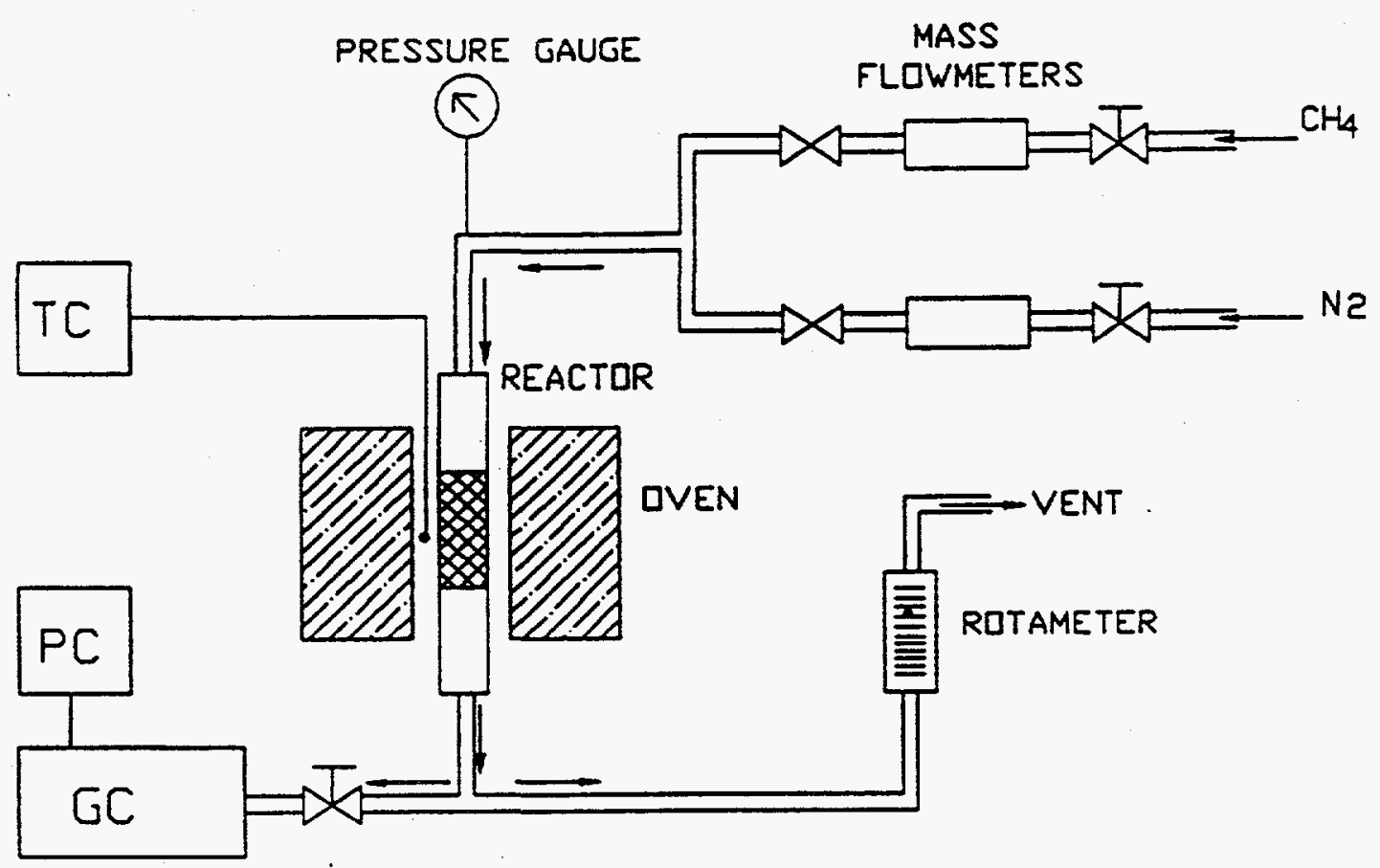

Figure 1. Schematic Diagram of Continuous Flow Thermocatalytic System for $\mathrm{CH}_{4}$ Cracking. Reactor Volume: $58.4 \mathrm{~mL}$. Catalyst: $6 \mathrm{~g}$. 

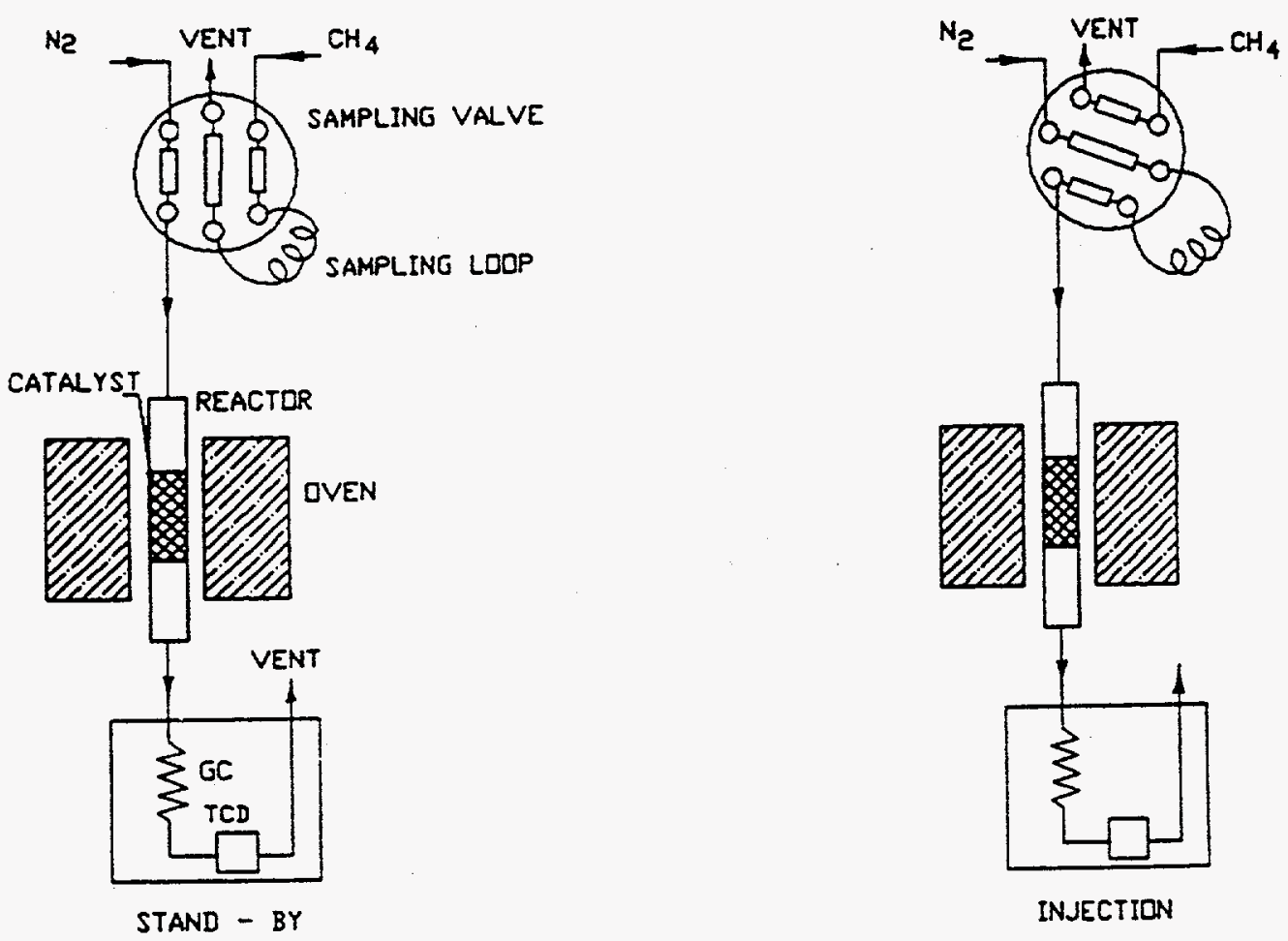

Figure 2. Pulse Reactor System for the Methane Thermocatalytic Cracking. Reactor Volume: $3.2 \mathrm{~mL}$. Catalyst: $0.5 \mathrm{~g}$. 


\subsection{RESULTS AND DISCUSSION}

\subsection{Temperature Dependence of Hydrogen Yield}

We studied thermocatalytic decomposition of methane over various catalysts and contacts in a wide range of temperatures $500-900^{\circ} \mathrm{C}$. It was observed that the hydrogen production rate is a function of the temperature. Figure 3 depicts the temperature dependence of the hydrogen concentration (\% vol) in the effluent gas using different catalysts and refractory materials including the reactor material: quartz. It was found that quartz as well as graphite and alumina showed no or insignificant activity in the methane decomposition reaction at temperatures below $700^{\circ} \mathrm{C}$. Alumina-supported Ni-Mo and Fe-catalysts demonstrated high catalytic activity in the range of $650-800^{\circ} \mathrm{C}$ and $800-900^{\circ} \mathrm{C}$, respectively. It should be noted that in some cases we observed a decline in the hydrogen yield as the run proceeded due to the carbon build-up on the catalyst surface. Therefore, only maximum values of hydrogen yields were considered in plotting the temperature dependence of the methane decomposition reaction.

It was observed that the shape of the kinetic curve for hydrogen production is mostly determined by the chemical composition of the contact. For example, alumina-supported Ptcatalyst demonstrated high catalytic activity only during first several minutes and then the rate of the methane decomposition drastically dropped and reached the stationary level which corresponds to the hydrogen concentration in the effluent gas equal to approximately $20 \% \mathrm{vol}$. (Figure 4). In case of oxide type catalysts the maximum yield of hydrogen is reached after the induction period corresponding to the catalyst reduction to its metallic state. Figure 5 depicts the time dependence of $\mathrm{H}_{2}$ concentration in the product of the methane decomposition in presence of alumina-supported Fe-catalyst. After a relatively long induction period, the stationary process of methane decomposition over the catalyst surface with the formation of gas ( $95 \%$ vol. $\mathrm{H}_{2}$ ) was observed. It should be noted that in this experiment the hydrogen production rate did not decline for at least two hours. Another behavior was demonstrated by the aluminasupported Ni-Mo catalyst. The maximum hydrogen yield was reached after a short induction period $(5 \mathrm{~min}$ ) followed by slow decrease in the catalytic activity. The kinetic curves of the hydrogen and carbon oxides production in presence of Ni-Mo catalyst are shown in Figure 6 . 


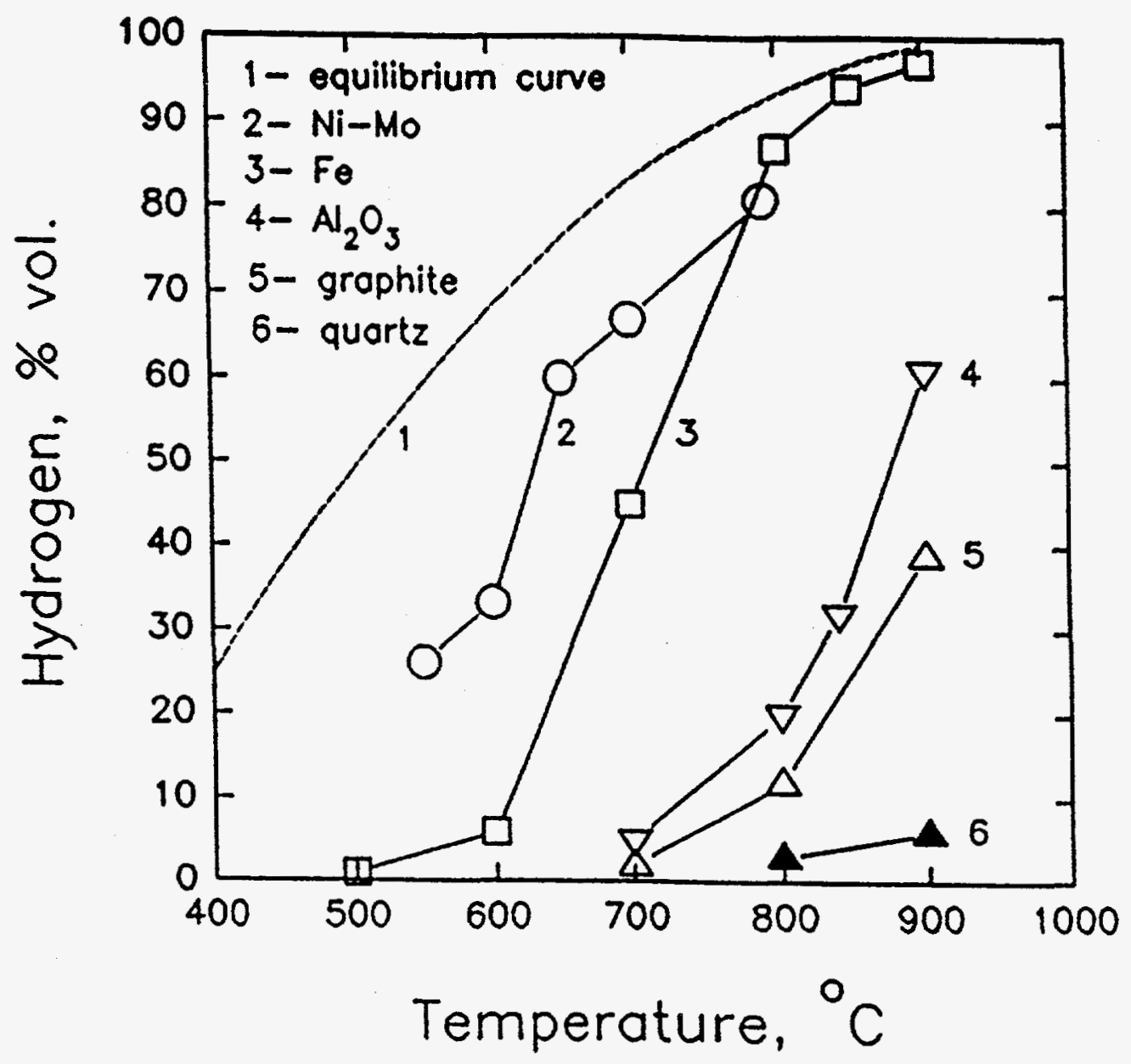

Figure 3. Temperature Dependence of Hydrogen Concentration in the Effluent Gas Using Various Catalysts and Contacts. Continuous Flow Reactor. 


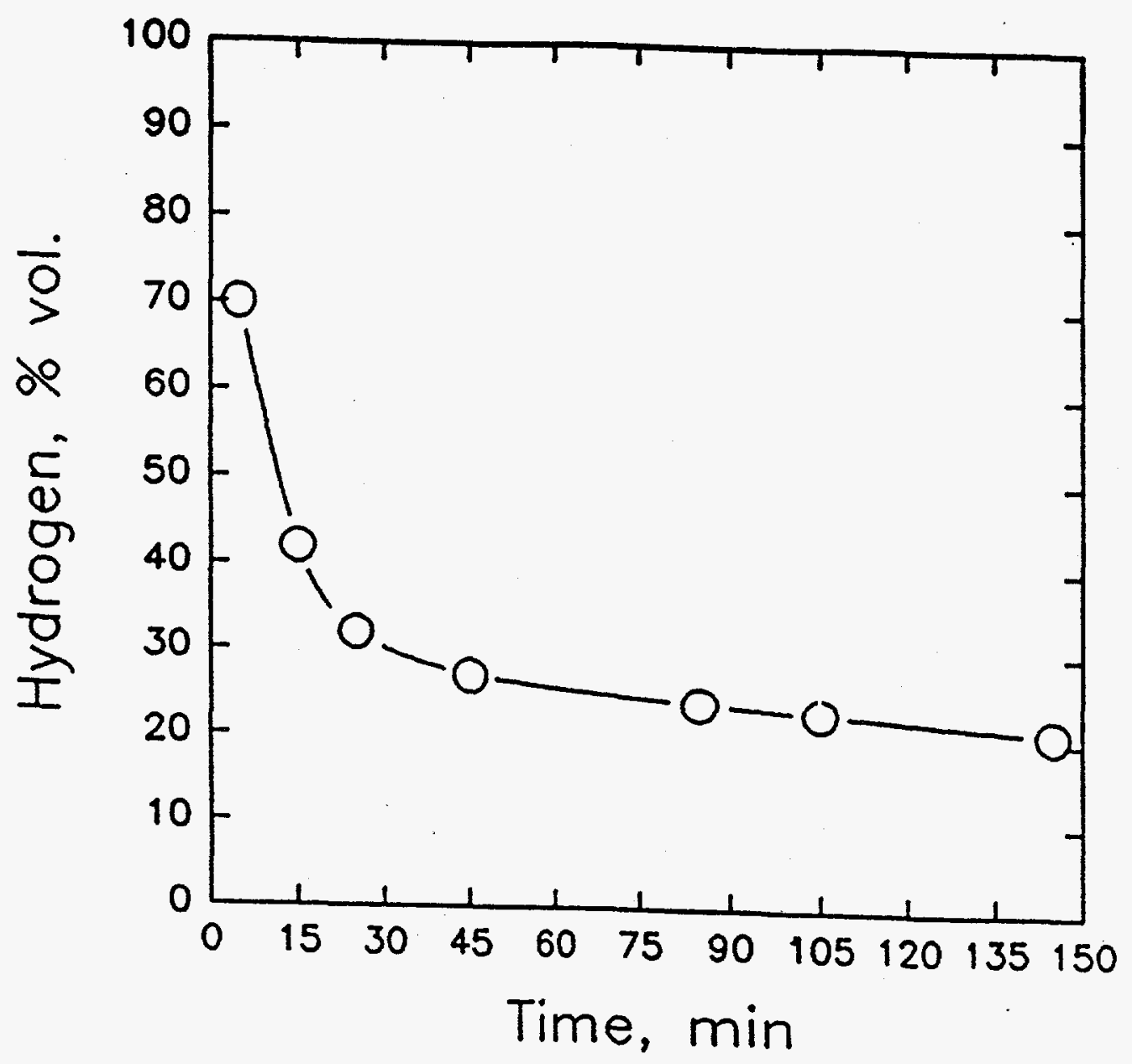

Figure 4. Time Dependence of Hydrogen Concentration in the Effluent Gas in the Presence of Alumina-Supported Pt-Catalyst. Continuous Flow Reactor. Temperature: $900^{\circ} \mathrm{C}$. 


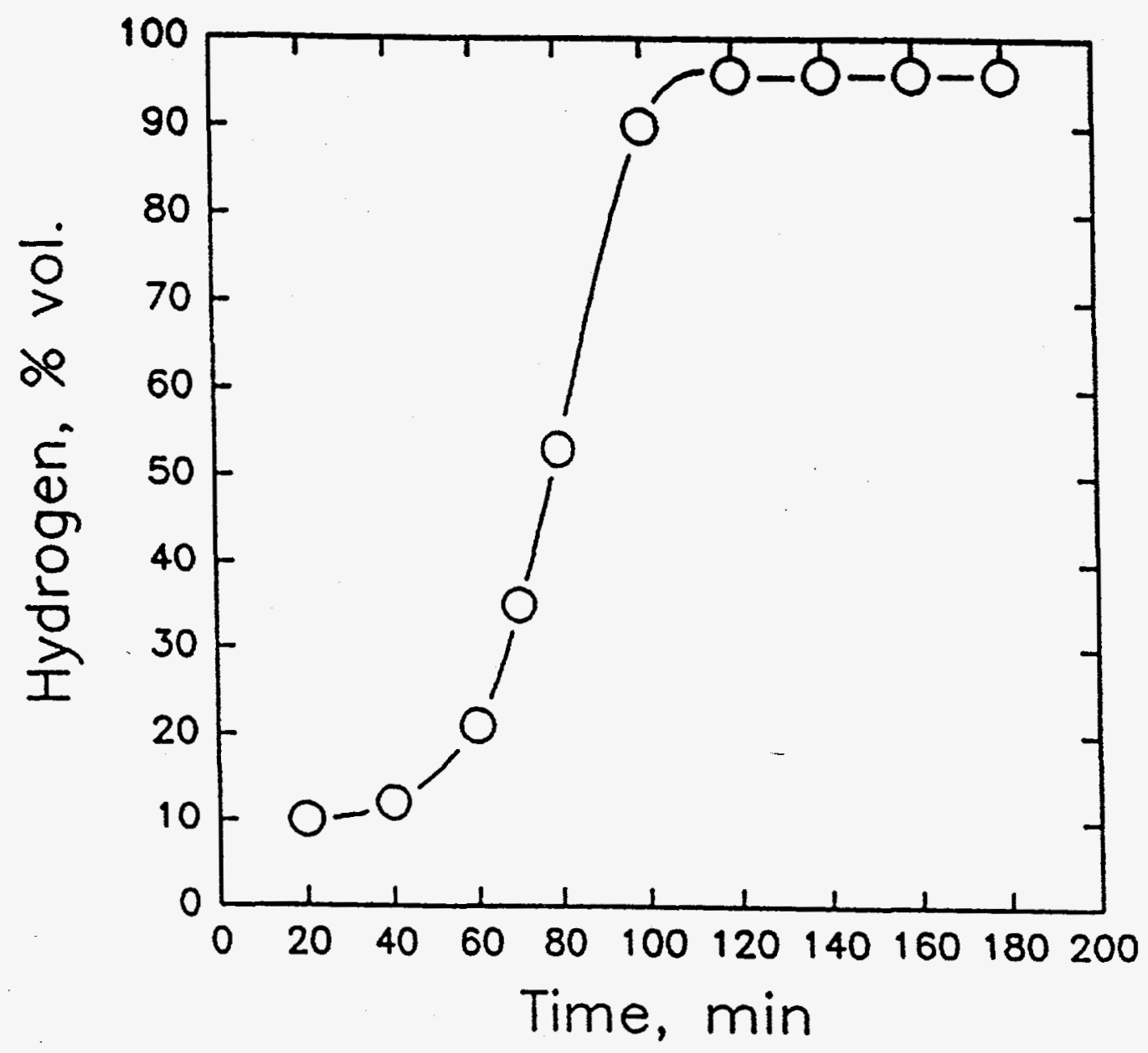

Figure 5. Time Dependence of Hydrogen Concentration in the Effluent Gas in the Presence of Fe-Catalyst. Continuous Flow Reactor. Temperature: $900^{\circ} \mathrm{C}$. 


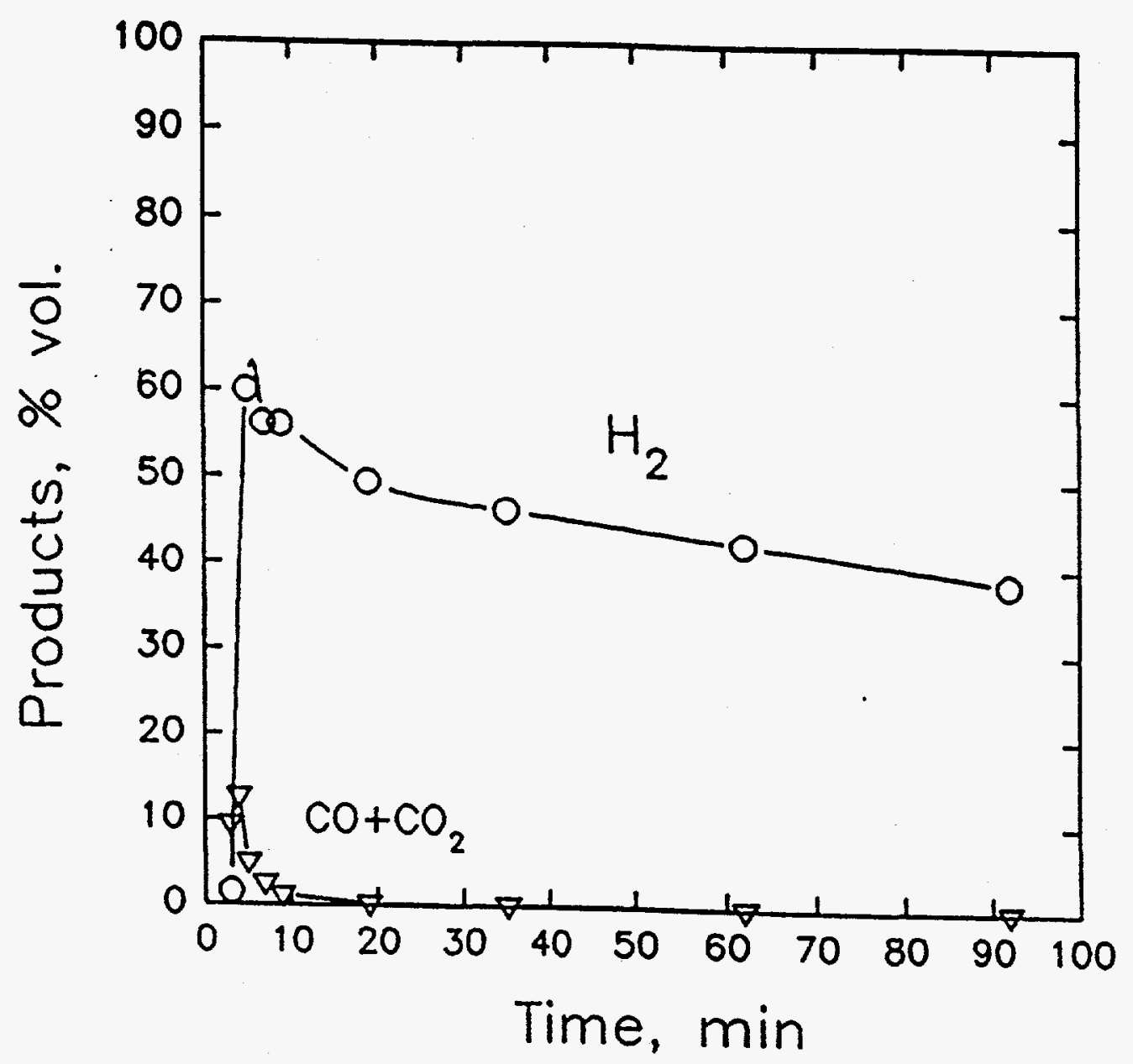

Figure 6. Time Dependence of Methane Decomposition Products Concentrations in the Effluent Gas Using Alumina-Supported Ni-Mo Catalyst. Continuous Flow Reactor. Temperature: $650^{\circ} \mathrm{C}$. 


\subsection{Space ¥elocity Dependence of Hydrogen Yield}

The rationale for this series of experiments was to study the effect of the residence time of methane within the continuous flow reactor on the hydrogen yield at given temperature. We conducted series of experiments on the methane catalytic cracking in wide range of flow rates from 25 to $450 \mathrm{~mL} / \mathrm{min}$ at $700^{\circ} \mathrm{C}$. $\mathrm{NiO}-\mathrm{MoO}_{3} /$ alimina was used as a catalyst. Figure 7 depicts the kinetic curves of hydrogen production at various flow rates. After short induction period 110 minutes hydrogen concentration in the effluent gas reaches the maximum value and then gradually declined. GC analysis showed that during induction period the effluent gas is rich with carbon oxides. Figure 8 shows the dependence of the maximum hydrogen yield on the space velocity of methane. Increase in methane space velocity from 3.8 to $67.8 \mathrm{~min}^{-1}$ resulted in significant drop in the hydrogen yield from 75.9 to $24.8 \%$.

\subsection{Pulse Reactor Experiments}

The continuous flow reactor experiments demonstrated that it was very difficult to accurately measure the maximum yields of hydrogen production. Relatively short induction period and the longevity of $\mathrm{GC}$ analysis (up to 7 minutes) were main sources of these difficulties. To solve this problem we problem we used pulse reactor, depicted in Figure $2.1 \mathrm{~mL}$ pulses of $\mathrm{CH}_{4}$ at regular intervals (corresponding to the time of $\mathrm{GC}$ analysis) were injected into the catalytic microreactor and the reaction products entered the GC analyzer. In a typical experiment we conducted up to 90 of such injections. Figure 9 depicts the dependance: the methane decomposition products yields $v s$ the number of $1 \mathrm{~mL}$ methane injections. First injections result in a deep oxidation of the methane into the carbon oxides and the reduction of the catalyst to its reduced (probably, metallic) form. We observed the onset of the hydrogen formation after 13 injections with the maximum hydrogen yield corresponding to $25-40$ injections. Beginning from the 30 th injection hydrogen was the only product of the methane decomposition. The most important result of this series of experiments is that the maximum concentration of hydrogen in the effluent gas is fairly close to its equilibrium (i.e. theoretical) value which is an indication of an active catalyst. 
It can be concluded from these experimental results that the induction period corresponds to the reduction of metal-oxide form of the catalyst into metallic form.

$$
\begin{aligned}
& 3 \mathrm{NiO}+\mathrm{CH}_{4}-3 \mathrm{Ni}+\mathrm{CO}+2 \mathrm{H}_{2} \mathrm{O} \\
& 12 \mathrm{Fe}_{2} \mathrm{O}_{3}+\mathrm{CH}_{4} \rightarrow 8 \mathrm{Fe}_{3} \mathrm{O}_{4}+\mathrm{CO}_{2}+2 \mathrm{H}_{2} \mathrm{O} \\
& 12 \mathrm{Fe}_{3} \mathrm{O}_{4}+\mathrm{CH}_{4}-12 \mathrm{FeO}+\mathrm{CO}_{2}+2 \mathrm{H}_{2} \mathrm{O} \\
& 3 \mathrm{FeO}+\mathrm{CH}_{4}-3 \mathrm{Fe}+\mathrm{CO}+2 \mathrm{H}_{2} \mathrm{O}
\end{aligned}
$$




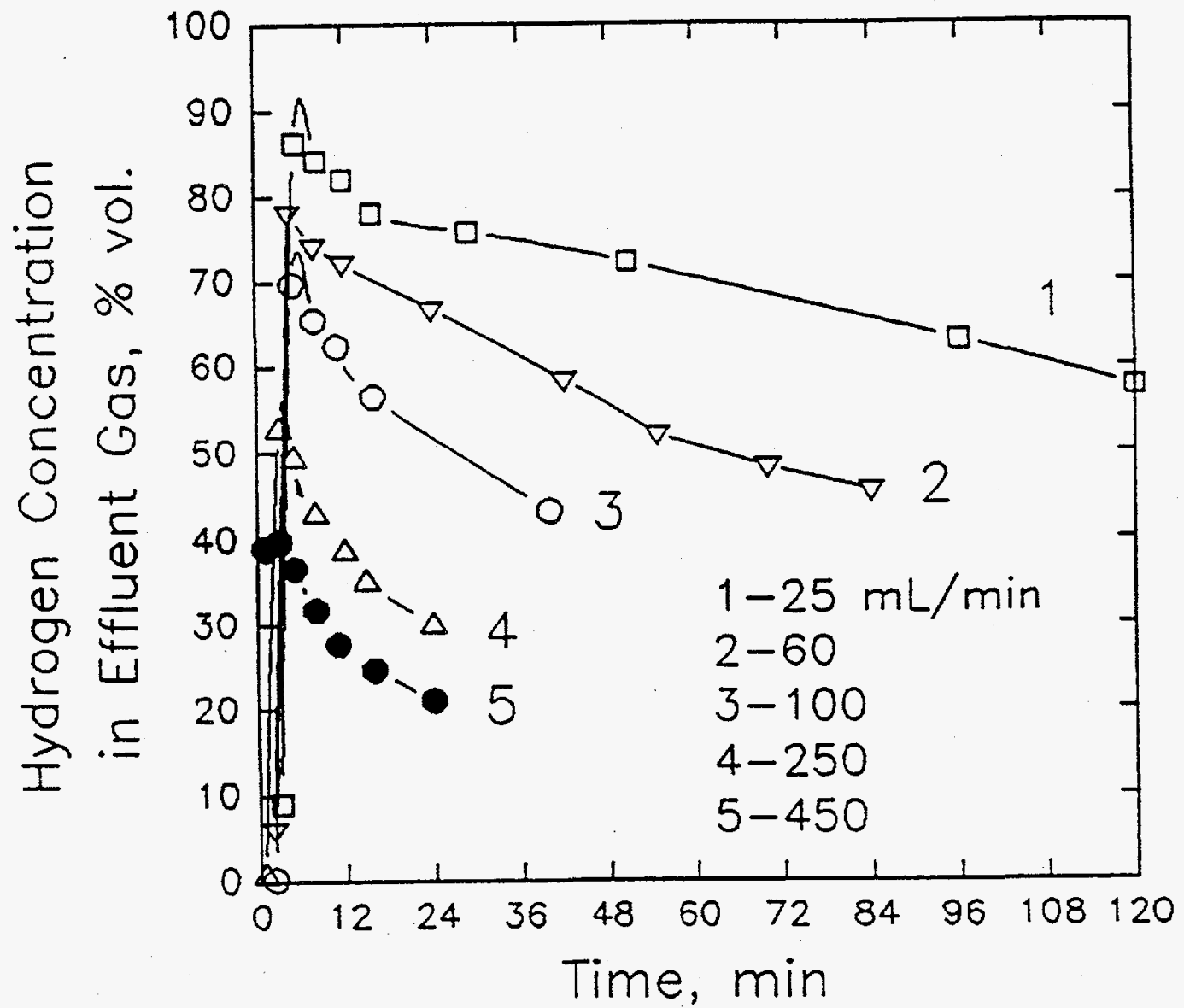

Figure 7. Kinetic Curves of Hydrogen Production at Different Flow Rates. Continuous Flow Reactor. Catalyst Ni-Mo/Alumina. Temperature $700^{\circ} \mathrm{C}$. 


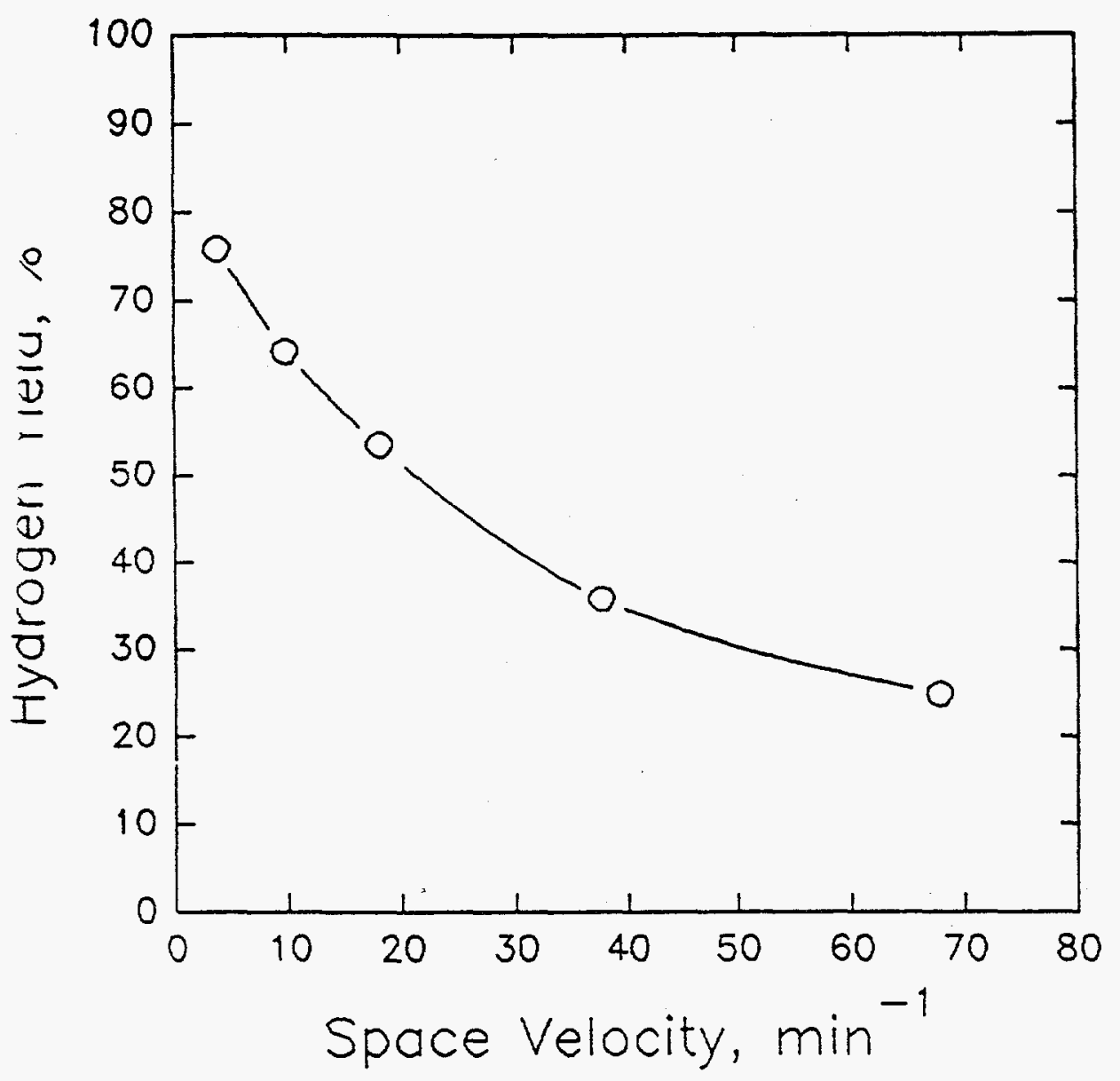

e 8. Hydrogen Yield us Space Velocity of Methane. Continuous Flow Reactor. Catalyst Ni-Mo/Alumina. Temperature $700^{\circ} \mathrm{C}$. 


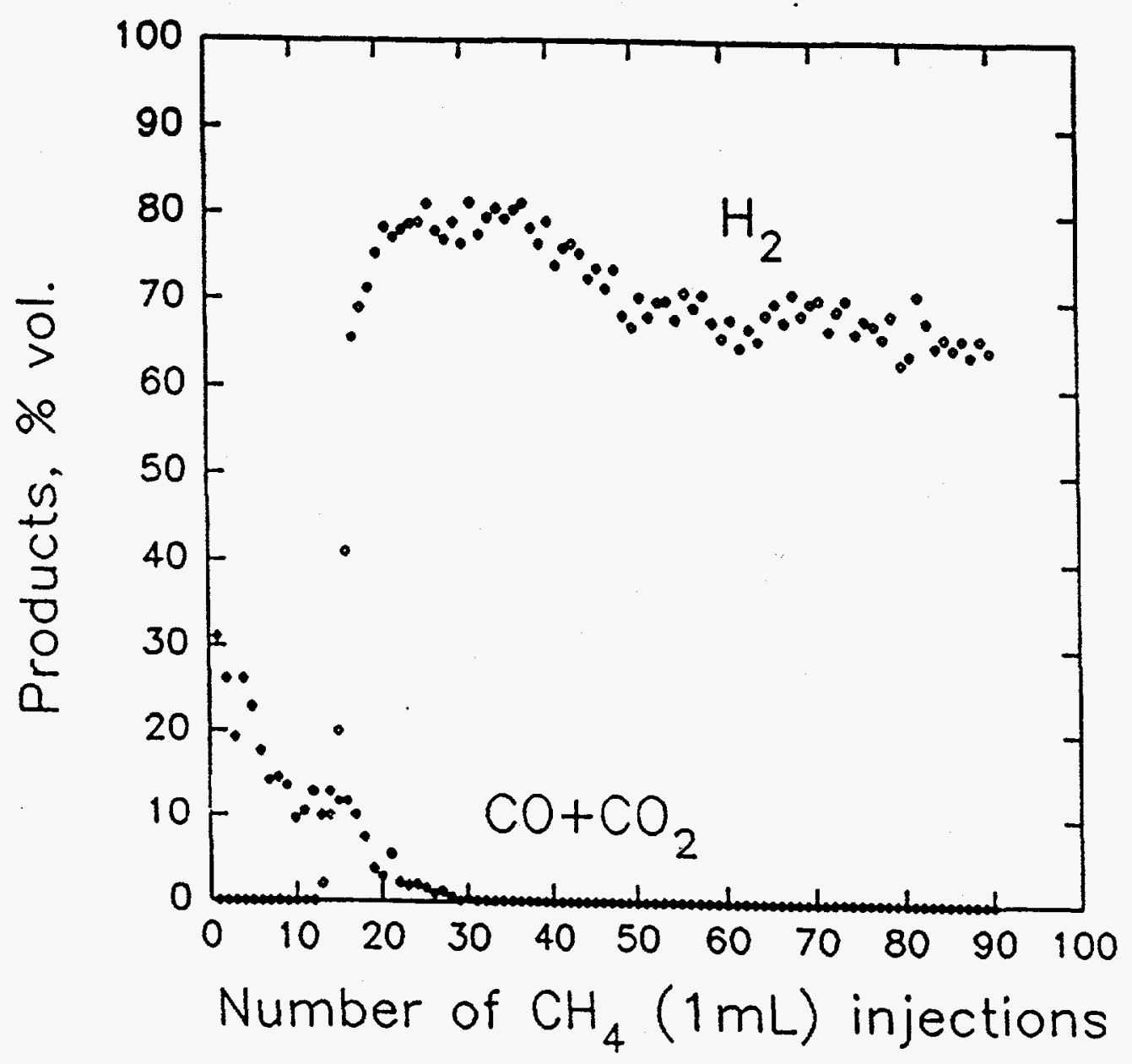

Figure 9. Methane Decomposition Products Concentrations in the Effluent Gas as a Function of the Number of Methane ( $1 \mathrm{~mL}$ ) Injections into Reactor. Pulse . Reactor. Alumina-Supported Ni-Mo Catalyst. Temperature: $650^{\circ} \mathrm{C}$. 
Once the active metallic form of the catalyst was produced, the effective cracking of methane molecules on the catalyst surface with formation of hydrogen and carbon begins. The carbon blocks the active sites on the catalyst surface which results in the reduction of the catalyst activity.

We have conducted SEM studies of the carbon deposited on the catalyst surface at different temperatures. After the catalytic cracking of methane, the reactor was allowed to cool to the room temperature in the stream of nitrogen. The carbon was carefully removed (mechanically) from the catalyst surface and analyzed by SEM method. Figure 10 depicts typical SEM micrograph of the carbon removed from Ni-Mo catalyst. It was found that the carbon formed on the catalyst surface at the range of temperatures $500-800^{\circ} \mathrm{C}$ had an amorphous structure. 


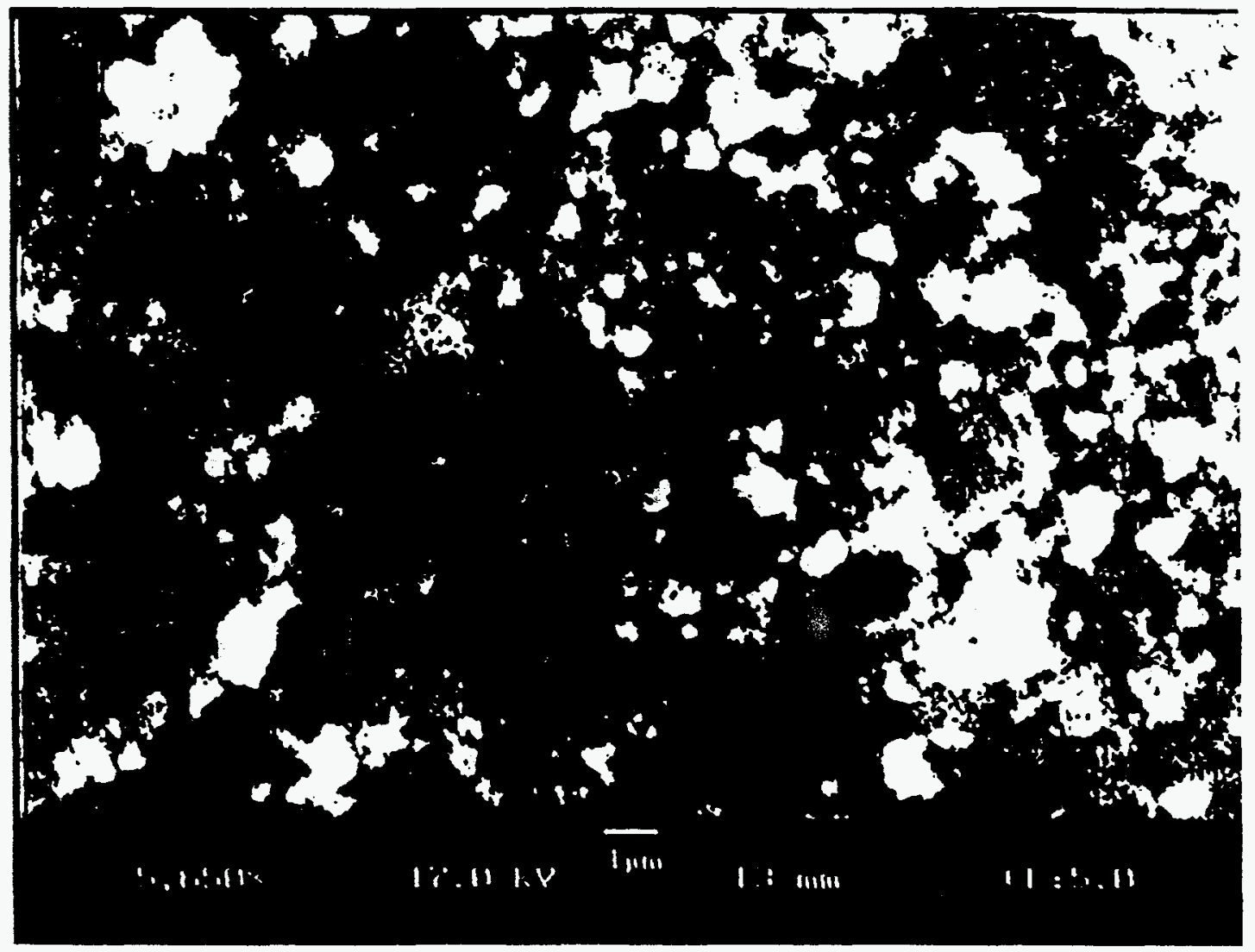

Figure 10. SEM Micrograph of Carbon Removed from Ni-Mo/Alumina Catalyst Surface. 


\subsection{CONCLUSIONS}

Thermocatalytic cracking of the natural gas has several advantages over conventional processes of hydrogen production: i) it is technologically simple one-step process, ii) it produces a valuable by-product: pure carbon and iii) it produces practically no $\mathrm{CO}_{2}$ emissions.

Thermocatalytic cracking of the methane over various catalysts and contacts was studied in this work. Catalyst activity and stability tests were conducted using two types of thermocatalytic systems: fixed bed continuous flow and pulse reactors, in a wide range of temperatures (500$900^{\circ} \mathrm{C}$ ) and space velocities $\left(3.8-67.8 \mathrm{~min}^{-1}\right)$. Alumina-supported Ni-Mo and bulk Fe catalysts demonstrated high catalytic activity at 650 and $800^{\circ} \mathrm{C}$, respectively. Pt/alumina catalyst rapidly lost its catalytic activity. Among materials tested quartz demonstrated lowest catalytic activity in methane decomposition reaction and, hence, can be used as a material for the reactor construction. It was found that the concentration of hydrogen in the effluent gas is a function of temperature and gas flow rate. For example, the $\mathrm{H}_{2}-\mathrm{CH}_{4}$ mixtures with the hydrogen concentration 30 and $80 \%$ vol. can be produced at 600 and $790^{\circ} \mathrm{C}$, respectively, using aluminasupported Ni-Mo catalyst. Fe-catalyst is thermally more stable than Ni-Mo/alumina catalyst and at elevated temperatures produces gas with the concentration of hydrogen up to $95 \%$ vol. The activity of the catalysts was tested using pulse catalytic reactor. The induction period preceded the effective hydrogen production using both $\mathrm{Ni}$ and $\mathrm{Fe}$ catalysts. It was found that the induction period corresponded to the reduction of metal oxide to metallic form of the catalyst. The carbon deposited on the catalyst surface was studied using SEM method. 


\subsection{REFERENCES}

1. Callahan, M. 1974. "Catalytic Pyrolysis of Methane and Other Hydrocarbons". In Proceedings of 26th Power Sources Symposium, 181-184. Red Bank, N.J.

2. Marchetti, C. and N. Nakicenovic. 1979. The Dynamics of Energy Systems and the Logistics Substitution Model, IIASA, RR-79-13, Laxenburg, Austria.

3. Nakicenovic, N. 1993. Energy Gases: The Methane Age and Beyond, IIASA Working Paper WP-93-033, Laxenburg, Austria.

4. Pohleny, J. and N. Scott. 1966. U.S.Patent No 3,284,161 (UOP).

5. Steinberg, M. and H. Cheng. 1988. "Modern and Perspective Technologies for Hydrogen Production from Fossil Fuels". In Proceedings of 7th World Hydrogen Energy Conference, 699-730. Moscow, USSR. 